\title{
КОГНІТИВНИЙ АСПЕКТ ПЕРЕКЛАДАЦЬКОГО ДИСКУРСУ
}

\author{
Тетяна Андріснко \\ tania_andrienko@ukr.net \\ Київський національний університет імені Тараса Шевченка
}

Received March, 27, 2016; Revised April, 19, 2016; Accepted April, 27, 2016

\begin{abstract}
Анотація. Статтю присвячено вивченню перекладу як особливого типу дискурсу, який розуміємо як процес та результат професійної когнітивно-комунікативної діяльності перекладача, у ході якої породжується і набуває мовного оформлення нова когнітивна сутність - концепт цільового тексту. Когнітивний аспект перекладацького дискурсу має ієрархічну структуру, яка складається 3 двох рівнів когнітивної організації дискурсу: когнітивно-регулятивного і когнітивно-репрезентативного. Стратегія перекладу розглядається як когнітивний регулятив, який управляє організацією i реалізацією перекладацького дискурсу. Стратегія спрямовує дискурсотворчу діяльність перекладача, яка полягає у пересотворенні концепту вихідного тексту для його інтеграції в іншу мовну культуру. Глобальній стратегії підпорядковані локальні, які, в свою чергу визначають тактики і прийоми та методи перекладу.
\end{abstract}

Ключові слова: перекладацький дискурс, когнітивно-комунікатвна діяльність, стратегія перекладу, тактика перекладу, когнітивний регулятив.

\section{Andriyenko, Tetiana. Cognitive Aspect of Translation Discourse.}

Abstract. The article is devoted to the study of translation as a special type of discourse which is understood as the process and the result of professional cognitive-communicative translator's activity in the course of which a new cognitive entity is generated and embedded through language means - the concept of the target text. The cognitive aspect of translation discourse has a hierarchical structure consisting of two levels of cognitive discourse organization: cognitive-regulatory and cognitive-representative. Translation strategy is seen as a cognitive regulative that controls the organization and implementation of the translation discourse. The strategy directs the translator's discourse creating activity which lies in the re-creation of the concept of the original text to integrate it into another language culture. Global strategies govern local strategies, which in turn determine the tactics and techniques and methods of translation.

Keywords: translation discourse, communicative cognitive activity, translation strategy, translation tactics, cognitive regulative.

\section{1. Вступ}

Розширення предмета дослідження лінгвістичних наук, залучення когнітивних, ситуативних та соціальних чинників привело до формування дискурсивного підходу до вивчення перекладознавчих проблем. Методологічне підгрунтя цього підходу складається під впливом компаративних досліджень дискурсивних чинників i категорій, універсального й ідеоетнічного в дискурсі (Кашкин, 2005), полілінгвальних досліджень концептів у дискурсі (Приходько, 2008). Ці студії оформлюються в окрему галузь зіставну концептологію - i накреслюють перспективи вивчення «способів концептуального устрою різних лінгвокультурних систем на тлі універсальних 
i етноспецифічних категорій, семіозис концептосфери, ідіо-, соціолектні, гендерні, вікові та інші схеми реалізації певних концептуальних конструктів у мові та мовленні» (Приходько, 2008: 83). Розуміння мови і мовлення як знакової діяльності людини в соціальній взаємодії, як знаряддя впливу, що має знакову (семіотичну) природу, а також бачення функції мови як «регулятивної функції» (Рудяков, 2004: 85) порушує питання когнітивної організації і комунікативної реалізації перекладу, який постає як мисленнєво-мовленнєва діяльність, яка здійснюється на перетині двох мов, із залученням щонайменше двох лінгвокультур і мовних картин світу.

За розуміння дискурсу як єдності мовного, когнітивного й комунікативного аспектів мисленнєво-комунікативної діяльності, що є сукупністю процесу й результату, i включає як позалінгвальний, так і власне лінгвальний аспект (Шевченко, 1998:38), стає очевидною актуальність дискурсивного підходу в перекладознавчих студіях. У сучасних дослідженнях переклад дедалі частіше розглядається не ізольовано, а як частина культурнолітературного процесу свого часу (Шмігер, 2009), як процес і результат діяльності творчої особистості - перекладача (Шевченко, 2005). Це визначає актуальність аналізу перекладу як особливого виду дискурсивної діяльності, визначення особливостей його організації та комунікативної реалізації.

\section{2. Огляд літератури}

Сучасне переосмислення поняття «дискурс» відбулося значною мірою завдяки опорі на принципово якісно відмінні від попередніх методологічні засади (Фролова, 2009: 43). Підхід до дискурсу як когнітивно-комунікативного явища зумовлений органічним поєднанням у ньому «актів когніції з актами комунікації» (Кубрякова, 1997: 188). Конвергентний розгляд когнітивних і комунікативних аспектів мовленнєвої діяльності (Приходько, 2008: 11) передбачає вивчення перекладу як єдності когнітивної i комунікативної складової. Бувши органічно пов'язаними, когнітивний i комунікативний аспект перекладацького дискурсу можуть вивчатися окремо, 3 метою якнайповнішого опису кожного. Дослідники дискурсу вважають, що таке поєднання не виключає, а передбачає домінування одного з напрямків аналізу: для дискурсивних розвідок характерне фокусування уваги на комплексі проблем мова і мислення / свідомість / знання, які являють собою предмет когнітивноорієнтованих студій, або ж на комплексі проблем мова як засіб / інструмент комунікації в соціокультурному континіумі, котрі становлять предмет комунікативно-дискурсивного аналізу (Белова, 2002: 17; Фролова, 2009: 43-44). Інтерес до вивчення механізмів породження перекладу, i, зокрема, формування перекладацької стратегії, змушує нас першочергово зосередитись на когнітивному аспекті перекладацького дискурсу, який в нашому розумінні постає як первинний, такий, що керує комунікативною реалізацією перекладу. Метою статті $\epsilon$ виявлення когнітивної структури перекладацького дискурсу, iii рівнів та складових, i, зокрема, місця стратегії в перекладацькій діяльності. Ця мета передбачає виконання таких завдань: виявлення характеру взаємодії когнітивних структур в перекладі; опис 
когнітивної структури перекладацького дискурсу; визначення місця стратегії в когнітивній організації перекладацького дискурсу. Дослідження проводилося із залученням комплексної методики, яка поєднує загальнонаукові методи опису, моделювання, порівняння та екстраполяції з методами когнітивного, компонентного аналізу і перекладознавчого порівняння.

У дискурсивно-орієнтованих дослідженнях переклад постає як взаємодія культур і картин світу. Погляд О. Г. Ревзіної на дискурс як глобальний процес зумовлює особливу оцінку функції перекладу у світі: «..матеріальну субстанцію дискурсу формують різні мови. Мовна концептуалізація, у якій втілюються національний менталітет i картина світу, $\epsilon$ основою поділу дискурсу за національною ознакою... переклад може розглядатися як дискурсивний процес, завдяки якому частково усуваються межі національних дискурсів і визначаються пріоритети дискурсу «всесвітнього» (Ревзина, 2005: 67). Ці ідеї суголосні 3 поглядами О.I. Чередниченка щодо взаємодії та зближення мовних i концептуальних картин світу внаслідок глобалізаційних процесів. Разом із тим, на думку перекладознавця, ці процеси не можуть призвести до повного нівелювання культурних розбіжностей (Чередниченко, 2002: 12). Роль перекладацького дискурсу слід вбачати не в подоланні культурних розбіжностей, а в ознайомленні носіїв мови перекладу з цінностями культури, до якої належить текст оригіналу. Грунтуючись на мовній та концептуальній картині світу одного соціуму (соціокультури), оригінал не може бути «Дзеркально» відтворений засобами іншої мови насамперед, через розбіжності в концептуальних картинах світу. Тож залучення положень когнітивної і дискурсивної лінгвістики до досліджень перекладу зумовлює зміну погляду на сам цей феномен: переклад постає як дискурсивний процес, спрямований на відтворення соціокультурних цінностей однієї мовної спільноти на грунті іншої мовної культури.

Аналізуючи когнітивну природу дискурсу, Тойн ван Дейк обгрунтовує гіпотезу по те, що найважливішим компонентом процесів породження та сприйняття текстів природними мовами $\epsilon$ осмислення $\mathrm{i}$ когнітивна репрезентація соціальних ситуацій, які стоять за ними (Дейк, 1989: 162). Проникнення в процеси сприйняття й породження текстів необхідне і для розуміння сутності перекладу, який об'єднує ці два види діяльності. Важливою для розуміння внутрішніх механізмів перекладацької діяльності вважаємо тезу Т. ван Дейка про наявність певних когнітивних моделей, сформованих на основі досвіду, які складають референційну базу для інтерпретації дискурсу. Такі моделі забезпечують швидкий та ефективний пошук, обробку i представлення інформації про соціальну ситуацію, впливають на оцінну класифікацію ситуацій (ван Дейк, 1989: 164 - 166). Породження текстів і дискурсу розглядається також як процес, що керується моделями ситуацій (Дейк, 1989: 169 - 171). Когнітивна теорія стратегічної обробки інформації відводить особливу роль стратегічному характеру продукування і сприйняття текстів; вона розглядає продукування і сприйняття текстів як гнучкий, багаторівневий процес обробки даних, здійснюваний в оперативному режимі. 
Екстраполюючи ідею контрольованості тексто- (i дискурсо-) породжувальної діяльності сформованими на основі досвіду індивіда когнітивними моделями на діяльність перекладача, слід перш за все припустити можливість існування розбіжностей таких моделей у представників різних етносів. Як стверджує А. М. Приходько, «У своєму прагненні підібрати ключик до розуміння етосу інших народів дослідники часто відштовхуються від своєї власної ментальності, тобто описують його крізь призму світобачення свого народу» (Приходько, 2008: 137). Виявлено також, що англомовні дослідники у вивченні особливостей фреймової репрезентації дійсності на матеріалі інших мов, несвідомо керуються англомовною картиною світу як основою аналізу (Rosman, Rubel, 2003: 270). «Сприймаючи інокультуру крізь призму своєї власної, ми мимоволі даємо їй суб'єктивну інтерпретацію, оцінюємо чуже крізь призму свого, добре відомого й пережитого - всього того, що існує в нас як у представника певного етнічного колективу» (Приходько, 2008: 141).

Компаративні лінгвокогнітивні та етнографічні дослідження підтвердили існування розбіжностей етнокультурної репрезентації дійсності, які простежуються на різних рівнях концепту: понятійного ядра (культурнодетерміновані прототипи) (McElhanon, 2005), асоціативного адстрату (розбіжності метафоричних та метонімічних картувань), ціннісно-оцінної складової (різна оцінка тих самих явищ) (Приходько, 2008). Ці розбіжності неодмінно виявляються в перекладі. Про концепт національної культури слід говорити в тому випадку, якщо при перекладі на іншу мову в такій мові немає дослівного еквівалента відповідного концепту (Карасик, 1998: 89). Принципово можливим переклад $є$ внаслідок існування певної універсальної бази знань, а також співіснування мовних картин світу вихідної та приймаючої культур у свідомості перекладача (Андрієнко, 2011: 53). Двомовна картина світу перекладача, яка уможливлює його посередництво між культурами, представлена на рис. 1.1:

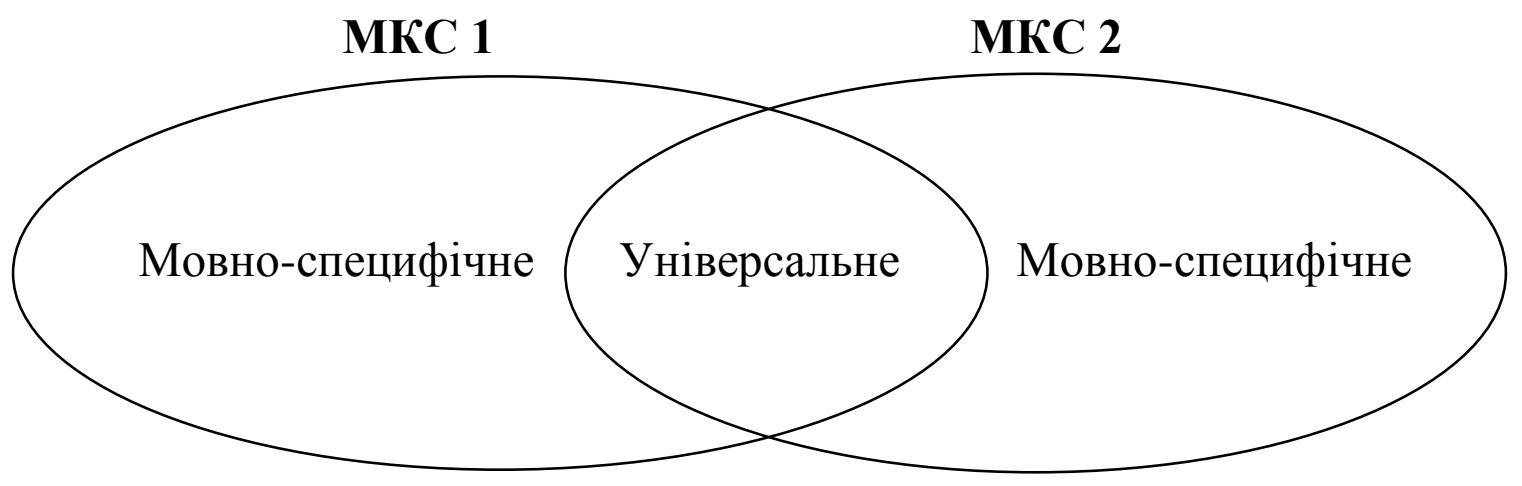

Рис. 1.1. Співіснування мовних картин світу в свідомості перекладача

Важливою передумовою успішного міжкультурного посередництва $\epsilon$ не володіння рівною мірою обома мовами, що видається малоймовірним, а розмежування структур репрезентації знань. 
Отже суттєво важливою характеристикою когнітивного аспекту перекладацького дискурсу вважаємо взаємодію в ньому когнітивних структур вихідної і цільової мовної картини світу. Саме внаслідок цієї взаємодії відбувається взаємозбагачення культур через переклад. Іноді запозичення концептів супроводжується розширенням лексичного складу за рахунок запозичення слів. Водночас, розвиток лексичного складу мови свідчить, що запозичені концепти не втрачають зв’язку зі своєю «рідною» культурою і в мові перекладу сприймаються як екзотизми, назви культурно-специфічних реалій тощо, що свідчить про неможливість «стирання» розбіжностей між культурами (Чередниченко, 2007:12).

Крім власне когнітивних структур, які взаємодіють в перекладі, когнітивно-дискурсивний підхід зумовлює інтерес до когнітивної організації перекладацького дискурсу як такого. Розуміючи дискурс як процес, організований на когнітивному рівні, розрізняємо два рівні когнітивної організації дискурсу: когнітивно-регулятивний (когнітивні структури, які забезпечують здійснення комунікації: знання про типи дискурсу i правила поведінки, стратегії, тактики тощо) і когнітивно-репрезентативний (когнітивні структури, які узагальнюють досвід концептуалізації світу і необхідні для інтерпретації ситуацій, представлених в дискурсі: концепти, фрейми, сценарії, як показано на рис. 1.2.

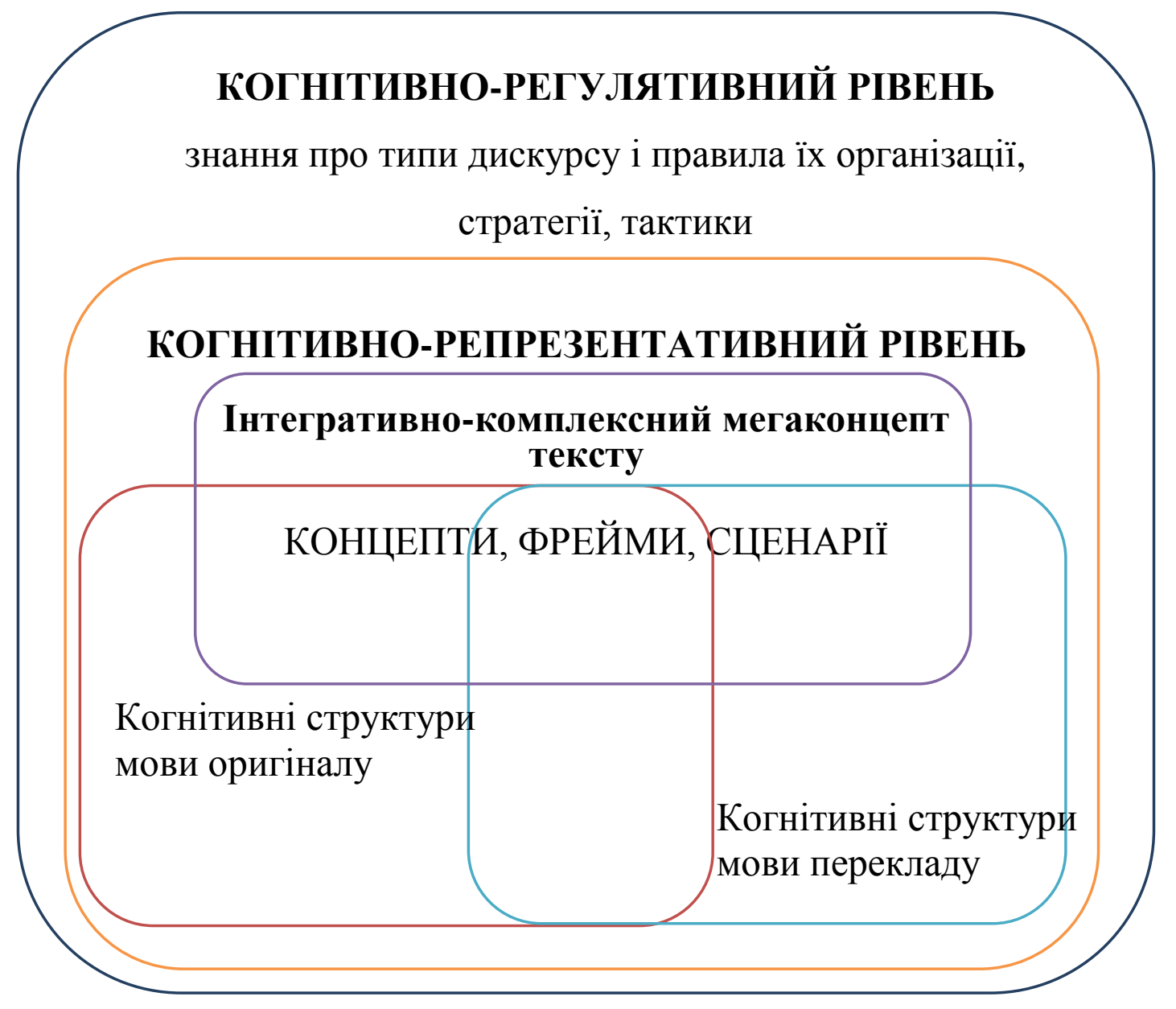

Рис. 1.2. Когнітивна структура перекладаџького дискурсу 
Вищий із цих рівнів досліджували переважно в теорії комунікації i прагматиці, де підгрунтя вивчення когнітивних регулятивів дискурсу закладено формулюванням принципів мовленнєвої взаємодії - принципу кооперації Г. П. Грайса i принципу ввічливості Дж. Ліча; П. Браун, С. Левінсона. Ці принципи було визначено на основі дослідження усного діалогічного мовлення, де аналіз обмежувався переважно рівнем речення або діалогічної єдності. Для перекладацького аналізу, в центрі уваги якого перебуває зазвичай цілісний текст як реалізація єдиної складної мовленнєвої інтенції автора, необхідний пошук правил, які організують мовлення на вищому рівні - тексту або дискурсу. Основи такого аналізу закладено в дослідженнях стратегій і тактик дискурсу, де стратегія трактується як «комунікативно-соціальна за своєю природою єдність чинників свідомості, мислення, мови/мовлення і визначається як комунікативний намір мовия, сформований на підставі використання суспільного досвіду для власних індивідуальних потреб і бажань, і мовна об'єктивація цього наміру, що надає йому інтерактивного статусу через осмислення вербалізованого наміру усіма суб'єктами» (Фролова, 2009: 85) (курсив автора). Розвиваючи ідею Т. ван Дейка про пріоритетну позицію глобальної стратегії, яка здійснює керування дискурсом (Дейк, 1989:274-277), стратегію розглядають як регулятор комунікативного процесу загалом. Отже пропонують розрізняти вербальні й невербальні стратегії (Белова, 2004: 14; Фролова, Андриенко, 2013), оскільки стратегічною $є$ не лише мовленнєва діяльність, а й ширша соціальна взаємодія, яка включає переконання, психологічний вплив тощо.

I. Є. Фролова доводить, що дискурсивна стратегія має ментальний корелят - концепт, ім'я якого $\epsilon$ назвою стратегії. У структурі концептуалізованого комунікативно актуального знання виділяються декларативний (прототип, стереотипи-уявлення) та процедуральний (стереотипи поведінки) складники. Саме наявність останнього - процедурального складника у концептуалізованому знанні забезпечує здатність певних концептів виступати ментальними корелятами дискурсивних стратегій, адже стереотипи поведінки, акумулюючи процедуральне знання, являють собою по суті готові «інструкції» дій або моделі поведінки (Фролова, Андриенко, 2013).

$\mathrm{y}$ перекладознавстві поняття «стратегія» використовується для опису програми діяльності перекладача під час інтерпретації інформації і створення тексту перекладу, яка має когнітивну природу (Krings, 1986; Loescher, 1991). Подібно до комунікативних стратегій, стратегії перекладу визначають й організують відбір мовних і мовленнєвих засобів. Проте, на відміну від комунікативної стратегії, стратегія перекладу грунтується на фахових знаннях. На думку В. Н. Комісарова, стратегія - це «своєрідне перекладацьке мислення, яке лежить в основі дій перекладача» і формується внаслідок спеціального навчання (Комиссаров, 2004: 356); Р. Яаскеляйнен описує стратегію як «низку компетенцій, дій або процесів отримання, зберігання та / або використання інформації» (Jaaskelainen, 1999: 71). Вибір стратегії може здійснюватися перекладачем як свідомо, так і несвідомо: «в основі перекладацьких стратегій 
лежить низка принципових настанов, якими свідомо чи несвідомо керується перекладач» (Дьяконова, 2004: 3-4); в англомовному перекладознавстві сформувалось уявлення про сутність стратегії як «потенційно свідомої» ("translator's potentially conscious plans" (Krings, 1986), “a potentially conscious procedure" (Loescher, 1991)). Під впливом тієї чи іншої стратегії перекладач здійснює вибір конкретного способу відтворення смислових, стилістичних, прагматичних ознак конкретної одиниці: калькування, компенсацію, пояснення тощо.

\section{3. Процедура дослідження}

Співвідношення поняття «стратегія» 3 широко вживаними теоретиками перекладу і практичними перекладачами поняттями «принципи перекладу», «методи i прийоми перекладу» $\epsilon$ гіпо-гіперонімічним: як відзначає В.Н. Комісаров, «Вироблення перекладацької стратегії передбачає знання i застосування перекладачем загальних принципів здійснення процесу перекладу, які включають три основних групи: певні вихідні постулати, вибір загального напрямку дій ... і вибір характеру і послідовності дій в процесі перекладу» (Комиссаров, 2004:356-357). Принцип перекладу є найзагальнішим теоретичним постулатом, який існує у свідомості перекладача незалежно від конкретного здійснюваного їм перекладу. Це узгоджується 3 загальнонауковим розумінням принципу як вихідного теоретичного положення.

Знання принципів перекладу $\epsilon$ постійним компонентом компетенції перекладача i стає основою вибору загального напрямку дій, яке співвідноситься із загальною (глобальної) стратегією перекладу.

Глобальну стратегію перекладу визначаємо як загальну когнітивну установку на транспонування текстового концепту оригіналу на когнітивні структури мовної картини світу цільової мови. Формування глобальної стратегії перекладу грунтується на застосуванні перекладачем загальних принципів перекладу до конкретного цілісного тексту. I принципи, і стратегії перекладу $\epsilon$ знанням, що формує напрямок діяльності - когнітивним регулятивом, який організує здійснення перекладацької діяльності в цілому.

Глобальна стратегія перекладу як когнітивний регулятий ієрархічно підпорядкована принципам перекладу i формується внаслідок вибору перекладачем основного (основних) принципів, які в даній ситуації видаються відповідними меті комунікації, когнітивним потребам і інтересам цільової аудиторії, i, на думку перекладача, враховують основні характеристики вихідного тексту, усвідомлені перекладачем як домінанти (певні характеристики смислу, форми, ідеостилю) або ж певні емпірично передбачувані характеристики перекладу.

Локальні стратегії перекладу визначаються як стратегії перекладу фрагментів тексту (рішення окремих перекладацьких проблем). У когнітивному плані в перекладацькій діяльності локальні стратегії включають аспекти «дискретизації» текстового концепту оригіналу, прочитання загального змісту тексту через його фрагменти, ідентифікації проблеми: 
виявлення конкретного фрагмента, який вимагає прийняття перекладацького рішення за існування альтернативності, i вибір напрямку / програми вирішення ідентифікованої проблеми в світлі глобальної стратегії перекладу.

Подібно до глобальних і локальних стратегій комунікації, стратегії перекладу не $\epsilon$ вибором мовної / мовденнєвої форми реалізації прийнятого рішення: вони залишаються сутностями когнітивного плану, що визначають концептуальний образ майбутнього перекладу в його співвідношенні 3 оригіналом. Вибір мовної одиниці або мовної форми визначається тактикою перекладу, яку, розвиваючи погляд В. В. Балабіна (Балабін, 2002), розглядаємо як визначення заданих стратегією смислових (денотативних, сигніфікативних, конотативних) і формальних характеристик майбутнього фрагменту цільового тексту. Вибір мовленнєвої реалізації або мовного елементу, який відповідає таким параметрам, являє собою прийом або метод (сукупність прийомів) перекладу.

\section{4. Обговорення результатів}

Стратегії й тактики перекладу різняться за характером об'єктів, на які вони спрямовані, або за рівнями когнітивних процесів, які вони контролюють. Необхідність розмежування стратегій і тактик перекладу пов'язана 3 ïх спрямованістю на різні об'єкти: у той час як локальна стратегія співвідноситься із загальним відтворенням концептуального смислу або функції фрагменту тексту, на який націлена діяльність перекладача, в той час як тактика визначає, які саме смислові або формальні характеристики мовних одиниць оригіналу (денотативного, сигнификативного, коннотативного значення, прагматичних або формальних характеристик) підлягають відтворенню в перекладі.

Наприклад, прагнучи відтворити ефект перебування в іншій країні, перекладач може вибрати стратегію відтворення іншомовних слів зі збереженням їх екзотичності (локальна стратегія очуження / форенізації). Ця стратегія передбачає такий набір тактик: повне збереження іншомовної форми (прийом безперекладного запозичення) без відтворення змісту або з його поясненням в коментарі або виносці; відтворення звукової або графічної форми засобами цільової мови (відповідно, прийоми транскрипції і транслітерації), які також можуть поєднуватися 3 коментарями або поясненнями; відтворення буквального значення («внутрішньої форми», яка мотивує образ) (прийом калькування). Тобто, визначення тактичних завдань дозволяє перекладачеві перейти до підбору відповідників у мові перекладу, які мали б певні змістовні або формальні характеристики.

Наприклад, тактика передачі графічної форми без експлікації смислу, i, відповідно, прийом безперекладного запозичення, обраний перекладачем роману Е. Гемінгвея на українську мову як реалізація локальної стратегії форенізації, дозволяє зберегти ефект відсторонення, перебування в чужій країні, і характерну рису ідеостілю автора: 
'That for you, Cabrón,' and the blow hit Don Benito in the face... (E. Hemingway. For Whom the Bell Tolls, p. 166)

"Ocb moбi, cabrón!»" ${ }^{1}$ Цього разу удар влучив в обличчя...

Стратегію очуження рідко застосовують при відтворенні емоцій, що можна пояснити прагненням перекладачів передати саме характер та інтенсивність почуттів, а не національну специфіку їх переживання чи вираження. У цитованому прикладі іспанський емоційний вигук, ужитий в англомовному тексті без перекладу та пояснень (із загального контексту зрозуміло, що це - інвектив), у перекладі відтворено завдяки безперекладному запозиченню, проте з перекладом та коментарем.

\section{5. Висновки}

Отже, сучасні перекладацькі студії трактують поняття стратегії в системі координат «мова-свідомість-комунікація», 3 урахуванням культурносоціальної позначеності усіх трьох складових та 3 наданням пріоритету чинникам свідомості й комунікації. Стратегія представляе когнітивний регулятив дискурсу, причому дискурс перекладу розуміємо як процес та результат професійної мисленнєво-комунікативної діяльності перекладача, у ході якої породжується i набуває мовного оформлення нова когнітивна сутність - концепт цільового тексту. Стратегія спрямовує дискурсотворчу діяльність перекладача яка полягає у пересотворенні концепту вихідного тексту для його інтеграції в іншу мовну культуру. Глобальній стратегії підпорядковані локальні, які, в свою чергу визначають тактики і прийоми та методи перекладу.

Розуміння перекладу як особливого типу дискурсу підводить нас до визначення стратегії як когнітивного регулятиву, який управляє організацією і реалізацією цього дискурсу; розвиток лінгвістичної теорії дискурсу створює підгрунтя для подальших досліджень - вивчення внутрішньої структури стратегії як концепту, визначення іiі місця серед інших регулятивів перекладацького дискурсу, виявлення типів стратегій, 3'ясування їх історичного та національно-культурного варіювання.

\section{Література}

References

1. Jaaskelainen, R. (1999). Tapping the process: an explorative study of cognitive and effective factors involved in translating. Joensuu: University of Joensuu Publications in Humanities.

2. Krings H. P. (1986). Translation Problems and Translation Strategies of Advanced German Learners of French. Interlingual and Intercultural Communication. Tubingen: Gunter Narr, 263-275.

3. Loescher W. (1991). Translation Performance, Translation Process and Translation Strategies. Tübingen: Gunter Narr.

${ }^{1}$ Досл.: иุап - іспанська лайка (Е. Хемінгуей. По кому подзвін Перекл. М. Пінчевський, c. 234) 
4. McElhanon, K. A. (2005) From Word to Scenario: The Influence of Linguistic Theories Upon Models of Translation. Journal of Translation, 1 (3), 29-67.

5. Rosman, A. and Paula G. Rubel (2003). Are Kinship Terminologies and Kinship Concepts Translatable? In: Translating cultures : perspectives on translation and anthropology. (pp. 269-283). Paula G. Rubel and Abraham Rosman (Eds.). Oxford, N.Y.

6. Андрієнко Т.П. Стратегії очуження й одомашнення в перекладі художнього дискурсу 3 англійської мови на українську: монографія. - К.: КиМУ, 2011. Andriyenko, T.P. (2011). Stratehiyi ochuzhennya y odomashnennya $v$ perekladi khudozhn'oho dyskursu $z$ anhliys'koyi movy na ukrayins'ku [Foreignizing and domestication strategies in translation of artistic discourse from English into Ukrainian]. Kyiv : KyMU.

7. Балабін В. В. Сучасний американський військовий сленг як проблема перекладу : автореф. дис. на здобуття наук. ступеня канд. філол. наук: спец. 10.02.16 «Перекладознавство» / В.В. Балабін. К., 2002.

Balabin, V. V. (2002) Suchasnyy amerykans'kyy viyskovyy slenh yak problema perekladu [Modern American Military Slang as a Problem of Translation]. Kyiv: Taras Shevchenko National University of Kyiv.

8. Бєлова А. Д. Комунікативні стратегії і тактики: проблеми систематики / А. Д. Бєлова // Мовні і концептуальні картини світу : зб. наук. пр. - К.: КНУ імені Тараса Шевченка, 2004. - С. 11-16.

Belova, A. D. (2004) Komunikatyvni stratehiyi i taktyky: problemy systematyky [Communication strategies and tactics: problems of taxonomy]. Movni $i$ Kontseptualni Kartyny Svitu, 11-16.

9. Дейк ван Т. А. Язык. Познание. Коммуникация / Дейк ван Т. А. ; [пер. с англ. ; сост. Петров В.В. ; под ред. Гарасимова]. - М. : Прогресс, 1989. - 310 с.

Dijk, T. van (1989). Yazyk. Poznaniye. Kommunikatsiya [Language. Knowledge. Communication]. Moscow: Progress.

10. Дьяконова Н.А. Функциональные доминанты текста как фактор выбора стратегии перевода : дис. ... канд. филол. наук : 10.02.20 / Наталья Анатольевна Дьяконова. M., 2004.

Djakonova, N.A. (2004) Funkcional'nye dominanty teksta kak faktor vybora strategii perevoda [Functional dominants of the text as a factor in the choice of the translation strategy]. Moscow.

11. Кашкин В. Б. Сопоставительные исследования дискурса / В. Б. Кашкин // Концептуальное пространство языка. - Тамбов: ТГУ, 2005. - С. 337-353.

Kashkin V.B. (2005). Sopostavitel'nye issledovanija diskursa [Comparative studies of discourse]. Konceptual'noe Prostranstvo Yazyka, 337-353.

Карабан В. И. Сложные речевые единицы: прагматика английских асиндетических полипредикативных образований : [монография] / Карабан В. И. - К. : Вища школа, 1989.

Karaban, V. I. (1989). Slozhnye Rechevye Yedinitsy: Pragmatika Angliyskikh Asindeticheskikh Polipredikativnykh Obrazovaniy [Complex Speech Act: Pragmatics of English Asynthetic Polypredicative Formations]. Kyiv: Vyshcha Shkola.

12. Карасик В. И. О категориях дискурса / В. И. Карасик // Языковая личность: социолингвистические и эмотивные аспекты : сб. науч. тр. - Волгоград-Саратов : Перемена, 1998. - С. 185-197.

Karasik, V. I. (1998) O Kategorijah Diskursa [On Discourse Categories]. In: Yazykovaja Lichnost: Sotsiolingvisticheskiye i Eemotivnye Aspekty. (pp. 185-197). VolgogradSaratov: Peremena.

13. Комиссаров В. Н. Современное переводоведение: Учебное пособие / Вилен Наумович Комиссаров. - М.: ЭТС, 2004.

Komissarov, V. N. (2004) Sovremennoye Perevodovedenye [Contemporary Translation Theory]. Moscow: ETS. 
14. Кубрякова Е. С. Части речи с когнитивной точки зрения / Е. С. Кубрякова. - М. : Инт языкознания РАН, 1997.

Kubrjakova E. S.(1997) Chasti Rechi s Kognitivnoy Tochki Zreniya [Parts of Speech from a Cognitive Perspective]. Moscow: Institut Yazykoznaniya RAN

15. Приходько А.М. Концепти і концептосистеми в когнітивно-дискурсивній парадигмі лінгвістики / Анатолій Миколайович Приходько - Запоріжжя: Прем'єр, 2008. Prykhodko, A. M. (2008). Kontsepty i kontseptosystemy v kohnityvno-dyskursyvniy paradyhmi linhvistyky [Concepts and concept systems in cognitive discourse paradigm of linguistics]. Zaporizhzhya: Premyer.

16. Ревзина О. Г. Дискурс и дискурсивне формации / О. Г. Ревзина. // Критика и семиотика. - Вып. 8. - Новосибирск, 2005 - с. 66 - 78. - Режим доступу: http://www.philology.ru/linguistics1/revzina-05.htm.

Revzina, O. G. (2005) Diskurs i diskursivne formatsii [Discourse and discursive formations]. Kritika $i$ Semiotika, 66-78. Retrieved from http://www.philology.ru/ linguistics 1/revzina-05.htm.

17. Рудяков А. Н. Язык или почему люди говорят (опыт функционального определения естественного языка) / Рудяков А. Н. - К. : Грамота, 2004.

Rudyakov, A. N. (2004). Yazyk ili Pochemu Lyudi Govoryat [Language, Or Why Do People Speak]. Kyiv: Gramota.

18. Чередниченко О.І. Про мову і переклад / Олександр Іванович Чередниченко. - К.: Либідь, 2007. - 248 с.

Cherednychenko, O. I. (2007). Pro Movu i Pereklad [On Language and Translation]. Kyiv: Lybid.

19. Шевченко I.C. Когнітивно-прагматичні дослідження дискурсу / I.С. Шевченко // Дискурс як когнітивно-комунікативний феномен / під загальн. ред Шевченко I. С.: Монографія. - Харків: Константа, 2005. - С. 105-117.

Shevchenko I.S. (2005). Kohnityvno-prahmatychni doslidzhennya dyskursu [Cognitivepragmatic discourse studies] Dyskurs yak Kohnityvno-Komunikatyvnyy Fenomen. Kharkiv: Konstanta.

20. Шевченко О. Н. Языковая личность переводчика: На материале дискурса Б. В. Заходера / Ольга Николаевна Шевченко: Дис. ... канд. филол. наук: 10.02.19 : Волгоград, 2005.

Shevchenko, O.N. (2005). Yazykovaja lichnost' perevodchika: Na materiale diskursa B. V. Zahodera [Language personality of the translator: based on Boris Zakhoder's discourse]. Volgograd.

21. Шмігер Т. Історія українського перекладознавства XX сторіччя / Тарас Шмігер. - К.: Смолоскип, 2009.

Shmiher, T. (2009). Istoriya Ukrayinskoho Perekladoznavstva XX Storichchya [History of Ukrainian Translation theory of the Twentieth Century]. Kyiv: Smoloskyp.

22. Фролова I. С. Стратегія конфронтації в англомовному дискурсі: Монографія / Ірина Свгенівна Фролова // Харків, 2009.

Frolova, I. Ye. (2009). Stratehiya Konfrontatsiyi v Anhlomovnomu Dyskursi [The Strategy of Confrontation in the English Discourse]. Kharkiv.

23. Фролова I. С., Андрієнко Т. П. Стратегії спілкування та стратегії перекладу / Ірина Фролова, Тетяна Андрієнко // Переклад у наукових дослідженнях представників харківської школи: колективна монографія / за ред.: Л. М. Черноватого, О. А. Кальниченка, О. В. Ребрія. - Вінниця : Нова Книга, 2013, С. 211 - 232.

Frolova, I. Ye., Andriyenko, T. P. (2013). Stratehiyi spilkuvannya ta stratehiyi perekladu [Communication strategies and strategies of translation]. In: Pereklad u naukovykh doslidzhennyakh predstavnykiv kharkivskoyi shkoly. (pp. 211 - 232). L. M. Chernovatyi, O. A. Kalnychenko, O. V. Rebriy, (Eds.). Vinnytsya: Nova Knyha. 